\title{
Kalah, Tapi Bisa Menang Strategi Kampanye Ahmad Heryawan-Deddy MIZWAR
}

\section{Eli Siti Wasliah}

\author{
Program Studi Magister Ilmu Komunikasi Pascasarjana Universitas Islam Bandung \\ email: eliesiti@gmail.com
}

\begin{abstract}
Abstrak. Strategi kampanye wajib dilakukan dalam sebuah pemilihan umum. Mulai dari pemilu presiden hingga pemilu kepala daerah. Ini dilakukan untuk memenangkan pertarungan tersebut. Ahmad Heryawan-Deddy Mizwar merupakan salah satu kandidat dari lima kandidat dalam Pemilu Gubernur dan Wakil Gubernur Jawa Barat tahun 2013. Kandidat nomor 4 ini menyusun strategi yang sungguh-sungguh dalam Pilgub Jawa Barat. Harapannya adalah bisa memenangkan Pilgub Jawa Barat. Tujuan penelitian ini untuk menganalisa dan membandingkan antara konsep strategi kampanye persuasif Richad M. Perloff dengan strategi kampanye pasangan Ahmad Heryawan-Deddy Mizwar. Paradigma yang digunakan dalam penelitian ini adalah konstruktivisme dengan metode penelitian menggunakan kualitatif dan pendekatannya studi kasus. Subjek penelitian adalah pasangan Ahmad Heryawan-Deddy Mizwar dan objek penelitiannya adalah komunikasi politik kampanye Ahmad Heryawan-Deddy Mizwar. Teori yang digunakan adalah Teori Identitas, Teori Logika Penyususnan Pesan, dan Teori Dialogis. Pengumpulan data dilakukan dengan wawancara, observasi, dokumentasi, sedangkan teknik analisis datanya dengan reduksi data, penyajian data, menarik kesimpulan, untuk uji keabsahan data menggunakan triangulasi dan ketekunan penelitian. Hasil dari penelitian ini menunjukkan bahwa Steategi memilih komunikator, memilih pesan, dan mengajak khalayak untuk berpikir dalam kampanye Ahmad Heryawan-Deddy Mizwar dalam Pilgub Jawa Barat tahun 2013 sesuai dengan yang dikemukakan oleh strategi kampanye persuasive Richard $M$. Perloff. Sementara itu faktor kemenangan Ahmad Heryawan-Deddy Mizwar dalam Pilgub Jawa Barat karena melaksanakan lima strategi, dampak dari perpolitikan nasional, dan pasrah dengan siap menang dan siap kalah. Kesimpulannnya bahwa strategi kampanye yang dilakukan dengan konsep yang jelas bisa menghasilkan kemenangan dalam pemilu.
\end{abstract}

Kata Kunci: Strategi Kampanye

\section{Pendahuluan}

Dalam satu dekade terakhir ini, sistem demokrasi pada pemilihan umum (pemilu) dilakukan secara langsung. Mulai dari pemilu presiden, DPR, kepala deaerah hingga kepala RT dipilih langsung oleh masyarakat. Sehingga butuh usaha, strategi, dan langkah yang ekstra dibanding dengan pemilihan yang dilakukan oleh DPR, DPRD, atau penunjukkan langsung. Termasuk dari sisi finansial, anggaran yang dikeluarkan pun lebih besar.
Tengok saja, partai politik semakin banyak. Hal ini melahirkan kandidat yang cukup banyak. Belum lagi dari calon dari independen. Banyak kandidat pemilu kepala daerah (pemilukada) di suatu daerah atau provinsi yang lebih dari 3 pasangan. Inilah realitas politik saat ini. Oleh sebab itu, diperlukan langkah dan strategi yang handal, agar proses pemilu dilakukan secara efektif dan efisien. Sehingga tujuan dan harapan untuk memenangkan pemilu bisa terwujud

Banyak strategi dalam praktik kampanye. Namun dari sekian banyak 
strategi tersebut peneliti tertarik untuk membahas strategi persuasi praktik kampanye dari pakar Komunikasi Politik, Richard M. Perloff. Ia menyarankan beberapa strategi persuasi yang dapat digunakan dalam praktik kampanye, yakni:

1. Pilihlah komunikator yang terpercaya

2. Kemasalah pesan sesuai keyakinan khalayak

3. Munculkan kekuatan diri khalayak

4. Ajak khalayak untuk berfikir

5. Gunakan strategi pelibatan

6. Gunakan strategi pembangunan inkonsistensi

7. Bangun resistansi khalayak terhadap pesan negatif

Untuk mengetahui teori tersebut dalam praktiknya, peneliti tertarik untuk membandingkan dengan kondisi kampanye pada pasangan Ahmad Heryawan-Deddy Mizwar dalam Pemilu Gubernur dan Wakil Gubernur (Pilgub) Jawa Barat Tahun 2013. Pasangan nomor urut 4 ini memenangkan pesta demokrasi lima tahunan di Provinsi Jawa Barat tersebut.

Di Provinsi Jawa Barat tahun 2013 lalu sudah dilaksanakan hajatan demokrasi lima tahunan yakni Pilgub Pilgub Jabar. Tepatnya pada 24 Februari. Pilgub Jabar diikuti oleh lima kandidat calon Gubernur dan wakil Gubernur Jawa Barat, yaitu pasangan pertama dari calon independen pasangan Dikdik Arief Mansoer-Nana Suryana Toyib. Kedua, Irianto M.S. Syafiudin-Tatang Farhanul Hakim (Yance-Tatang), pasangan ini diusung oleh Partai Golkar. Ketiga, Dede YusufLex Laksamana (Dede-Lex), pasangan ini diusung oleh Partai Demokrat, Partai Amanat Nasional (PAN), Partai Kebangkitan Bangsa (PKB), dan Partai Gerakan Indonesia Raya (Gerindra). Keempat pasangan Ahmad HeryawanDeddy Mizwar (Aher-Demiz) yang diusung oleh Partai Keadilan Sejahtera (PKS), Partai Persatuan Pembangunan (PPP), Partai Bulan Bintang (PBB), dan Partai Hati Nurani Rakyat (Hanura). Dan kelima pasangan Rieke Diah Pitaloka-Teten Masduki (Rieke-Teten) yang diusung oleh Partai Demokrasi Indonesia perjuangan (PDIP).

Jawa Barat merupakan provinsi dengan jumlah penduduk paling besar di antara provinsi lain. Jumlah penduduknya Jawa Barat mencapai 44 juta jiwa pada tahun 2013. Saat proses penyelenggaraan Pilgub Jabar jumlah daftar pemilih tetap (DPT) mencapai 33,2 juta jiwa. Pelaksanaan pemilihan diselenggarakan pada Minggu 24 Februari 2013. Hasil quick count sejumlah lembaga survey matoritas memastikan bahwa pasangan Ahmad Heryawan-Deddy Mizwar (AherDemiz) memenangkan pertarungan Pilgub Jabar.

Pada Minggu, 3 Maret 2013, Komisi Pemilihan Umum (KPU) Jawa Barat berhasil merampungkan perhitungan suara manual di 26 kabupaten/kota melalui rapat pleno yang diselenggarakan di Kantor KPU Jawa Barat, Jln. Garut, Kota Bandung. Hasilnya, pasangan nomor urut 4, Ahmad Heryawan dan Deddy Mizwar meraih suara terbesar, yakni 6.515.313 suara. Urutan kedua dimenangkan oleh pasangan nomor 5, Rieke Diah Pitaloka dan Teten Masduki dengan memperoleh 5.714.997 suara. Di posisi ketiga, ditempati pasangan nomor urut 3, Dede Yusuf-Lex Laksamana dengan raihan 5.077.522 suara. Disusul pasangan Irianto M.S. Syafiudin-Tatang Farhanul Hakim dengan raihan 2.448.358 suara. Urutan terakhir pasangan calon independen Dikdik Mulyana dan Cecep NS., Toyib dengan memperoleh 359.233 suara.

Jumlah suara sah dalam Pilgub Jabar sebanyak 20.115.423 suara, dan suara tidak sah 598.356 suara. Total 
suara sah dan tidak sah sebanyak 20.713.779 suara. Dengan demikian dari jumlah DPT yang berjumlah 32,5 juta jiwa, sekitar 63 persen masyarakat Jawa Barat menggunakan hak pilihnya, dan 37 persen tidak menggunakan hak pilihnya.

Kemenangan pasangan AherDemiz tentunya tidak dengan sendirinya. Selain usaha yang dilakukan kedua pasangan politisi-budayawan tersebut dan partai pengususng serta pendukung, juga banyak orang yang berada di sekitarnya. Khususnya para tim kampanye atau tim sukses, juga relawan kedua pasangan Aher-Demiz. Keberhasilan pemenangan dalam pilkada membuktikan cukup besarnya dukungan dan kepercayaan rakyat terhadap pasangan yang diusung.

Padahal, berdasarkan catatan peneliti setidaknya hingga waktu menjelang pilgub, nama Ahmad Heryawan masih kalah popular dari calon yang lain, yakni Dede Yusuf yang saat itu menjadi Wakil Gubernur Jabar. Ahamd Heryawan selalu berada di posisi kedua dari sejumlah lembaga survei yang melakukan survei pilgub. Di akhir-akhir menjelang pilgub hanya tim kampanye Aher-Demiz yang menyebutkan bahwa surveinya memenangkan pasangan nomor 4 ini.

Tentunya kemenangan AherDemiz bukan perkara mudah. Memerlukan strategi pemenangan yang matang dan mendalam khususnya dalam proses kampanye. Hal inilah yang menjadi ketertarikan peneliti untuk meneliti lebih jauh terkait strategi kampanye pasangan Aher-Demiz pada Pilgub Jabar tahun 2013 yang dikaitkan dengan strategi kampanye yang dikemukankan oleh Richard M. Perloff.

Namun, dari 7 strategi yang dikemukakan, peneliti hanya akan menggunakan 3 strategi, yaitu: pertama, pilihlah komunikator yang terpercaya. Kedua, kemasalah pesan sesuai keyakinan khalayak. Ketiga ajaklah khalayak untuk berpikir. Alasannya, pertama, ketiganya sudah memenuhi standar pola komunikasi dua arah, yaitu adanya komunikator, komunikan, dan pesan. Kedua, dalam menyusun strategi kampanye ketiga faktor itu juga yang lebih banyak digunakan.

\section{Metode}

Penelitian ini menggunakan jenis penelitian kualitatif. Metode adalah teknik-teknik spesifik dalam penelitian. Metode penelitian kualitatif adalah riset yang bersifat deskriptif dan cenderung menggunakan analisis dengan pendekatan induktif. Proses dan makna (perspektif subjek) lebih ditonjolkan dalam penelitian kualitiatif. Landasan teori dimanfaatkan sebagai pemandu agar fokus penelitian sesuai dengan fakta di lapangan. Selain itu, landasan teori juga bermanfaat untuk memberikan gambaran umum tentang latar penelitian dan sebagai bahan pembahasan hasil penelitian.

Pendekatan penelitian ini adalah menggunakan studi kasus. Studi kasus adalah salah satu metode penelitian ilmu-ilmu sosial. Studi kasus diartikan sebagai metode atau strategi dalam penelitian untuk mengungkap kasus tertentu. Ada juga pengertian lain, yakni hasil dari suatu penelitian sebuah kasus tertentu. Jika pengertian pertama lebih mengacu pada strategi penelitian, maka pengertian kedua lebih pada hasil penelitian. Sebuah definisi dengan bersifat teknis sehingga sangat membantu tentang studi kasus diberikan oleh (Yin, 2005:18), yang menyebutkan bahwa studi kasus adalah suatu inkuiri empiris yang: menyelidiki fenomena dalam konteks kehidupan nyata, bilamana; batas-batas antara fenomena dan konteks tak tampak dengan tegas; dan di mana: multi sumber bukti dimanfaatkan. 


\begin{abstract}
Sedangkan paradigma yang dilakukan dalam penelitian ini menggunakan paradigma Konstruktivisme merupakan paham yang menyatakan bahwa semesta secara epistimologi merupakan hasil konstruksi sosial. Pengetahuan manusia adalah konstruksi yang dibangun dari proses kongnitif yang berinteraksi dengan dunia objek material. Pengalaman manusia terdiri atas interpretasi bermakna terhadap kenyataan dan bukan reproduksi kenyataan. Dengan demikian, dunia muncul dalam pengalaman manusia secara terorganisasi dan bermakna. Keberagaman pola konseptual (konginitif) merupakan hasil dari lingkungan historis, kultural, dan personal yang digali terus menerus. (Ardianto dan Q-Aness, 2009).
\end{abstract}

\section{Temuan dan Pembahasan}

Penetapan strategi merupakan langkah krusial yang memerlukan penanganan secara hati-hati dalam kampanye sebab jika penetapan strategi salah atau keliru, hasil yang diperoleh bisa fatal, terutama kerugian dari segi waktu, materi, dan tenaga. Oleh karena itu, strategi juga merupakan rahasia yang harus disembunyikan oleh para ahli perencana kampanye.

Dengan adanya kampanye yang dilakukan oleh para calon kapala daerah secara langsung, masyarakat akan melihat dan mengenal calon tersebut. Hal ini akan dimanfaatkan oleh elit partai untuk menyosialisasikan program, kerja calon pasangan Gubernur dan Wakil Gubernur Jawa Barat sesuai dengan visi dan misinya. Hasil penelitian dalam Pemilihan Gubenur dan Wakil Gubernur Jawa Barat yang diikuti oleh lima pasangan calon. Pertarungan politik ini dimenangkan oleh Pasangan Ahmad Heryawan-Deddy Mizwar.
Hasil penelitian ini menyimpulkan bahwa pertama strategi kampanye yang dilakukan Ahmad Heryawan-Deddy Mizwar ditentukan oleh tim kampanye bersama pasangan calon. Ada lima strategi yang disusun untuk memenangkan pasangan Ahmad Heryawan-Deddy Mizwar dalam Pilgub Jawa Barat tahun 2015. Yakni penentuan pasangan calon yang layak jual, menguatkan mesin partai dan kader, pendanaan, janji kampanye, dan peranan media.

Strategi memilih komunikator yang terpercaya yang dilakukan pasangan Ahmad Heryawan-Deddy Mizwar adalah melalui pasangan calon, juru kampanye, dan kader partai. Mereka yang terpilih adalah yang dapat dipercaya dengan memiliki kredibilitas. Sekalipun komunikator itu kader partai, tapi mereka dibekali tools pesan yang sudah rapi sesuai dengan janji kampanye. Apa yang dilakukan oleh pasangan Ahmad Heryawan-Deddy Mizwar ini sesuai dengan yang dikemukakan dalam konsep kampanye persuasif Richard M. Perloff, yakni pilihlan komunikator yang terpercaya.

Dalam kerangka kampanye persuasifnya Richard M. Perloff, memilih komunikator yang terpercaya dalam kampanye sangatlah penting. Sebab pesan yang diorganisasikan dan disampaikan dengan baik belum cukup untuk mempengaruhi khlayak. Diperlukan juga komunikator yang terpecaya untuk menyampaikan pesan tersebut. Semua bukti di dunia menunjukan bahwa pesan yang diracang dan yang disampaikan dengan sumpurna tidak akan dapat membawa perubahan perilaku jika khalayak tidak memercayai komunikator (Larson, 1992). Karena alasan ini maka kredibilitas komunikator merupakan hal yang harus diperhatikan agar ia bisa menjadi pembawa pesan yang dapat dipercaya Kredibilitas adalah persepsi 
yang dimiliki khalayak tentang komunikator. Ia merupakan kerangka perseptual khalayak tentang komunikator dan bukan karakteristik komunikator itu sendiri (Hovland dalam Larson, 1953). Karenanya kredibilitas yang dimiliki komunikator harus sesuai dengan khalayak yang dapat dituju. Seorang bidan akan dipersepsi baik sebagai seseorang yang serba tahu tentang kandungan ketika sedang memberikan penyuluhan kesehatan kandungan di sebuah desa terpencil. Tapi tidak demikian halnya jika ia menjadi pembicara pada sebuah seminar kesehatan kandungan yang bertaraf nasional.

\section{Gambar 1. Strategi Memilih}

\section{MEMIIH KOMUNIKATOR TERPERCAYA}

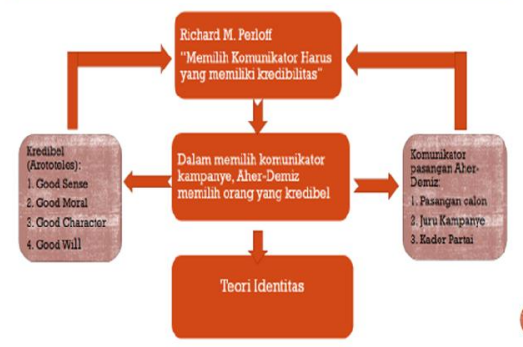

Komunikator yang Terpercaya

Strategi memilih pesan yang seusai dengan keyakinan khalayak yang dilakukan pasangan Ahmad HeryawanDeddy Mizwar adalah dilakukan dalam bentuk langsung (melalui kampanye, silaturahmi, dll), maupun tidak langsung (melalui media), Materi pesannya berisi tentang keberhasilan Ahmad Heryawan, janji kampanye, dan program kerja. Pesan yang disampaikan tidak bohong dan tidak manipulasi, benar adanya. Sementara isi pesannya umum (disampaikan saat kampanye) dan khusus (disampaikan pada komunitas tertentu). Pesan yang disampaikan harus menjadi kepercayaan dari khalayak.
Apa yang dilakukan oleh pasangan Ahmad Heryawan-Deddy Mizwar ini sesuai dengan apa yang dikemukakan dalam konsep kampanye persuasif Richard M. Perloff, yakni kemaslah pesan sesuai dengan keyakinan khalayak. Menurutnya, pesan akan dapat mempunyai pengaruh yang besar untuk mengubah perilaku khalayak jika dikemas dengan kepercayaan yang ada pada diri khalayak. Karenannya dari tujuan dan tema utama kampanye hendaknya dibuat pesan-pesan yang sesuai dengan kepercayaan khalayak.

Gambar 2. Strategi Mengemas Pesan Sesuai Keyakinan Khalayak

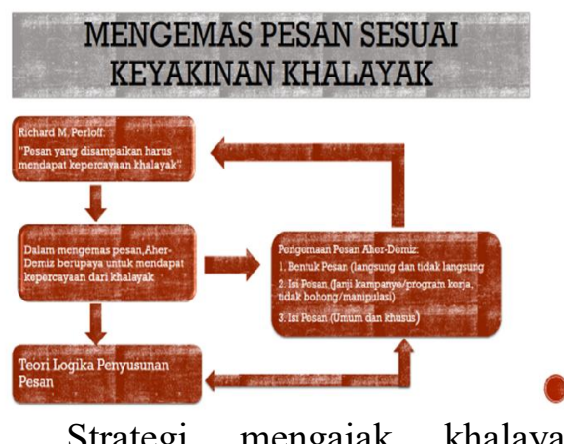

Strategi mengajak khalayak berpikir saat kampanye pada pasangan Ahmad Heryawan-Deddy Mizwar pada Pilgub Jawa Barat dilakukan dengan dialog, turun ke jalan, dan melakukan kegiatan yang bersentuhan dengan emosi dan budaya, dll. Apa yang dilakukan oleh pasangan Ahmad Heryawan-Deddy Mizwar ini sesuai dengan apa yang dikemukakan dalam konsep kampanye persuasif Richard M. Perloff, yakni ajaklah khalayak untuk berfikir.

Ia berpendapat bahwa sebuah pesan dapat membawa perubahan perilaku jika dapat memunculkan pemikiran postif dalam diri khalayak. Pemikiran positif ini dapat diperoleh dengan menyampaikan keuntungankeuntungan dan menujukan bahwa pemikiran-pemikiran negatif khalayak adalah tidak benar adanya. Menyajikan 
data-data statistik dan temuan-temuan penelitian yang relevan, menanyakan alasan khalayak merupakan sesuatu atau sekedar memberikan argumentasi yang masuk akal adalah beberapa cara yang dapat mendorong khalayak berpikir.

Gambar 3 Strategi Mengajak Khalayak Berpikir

Faktor kemenangan Ahamd Heryawan-Deddy Mizwar dalam Pilgub

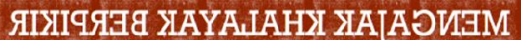

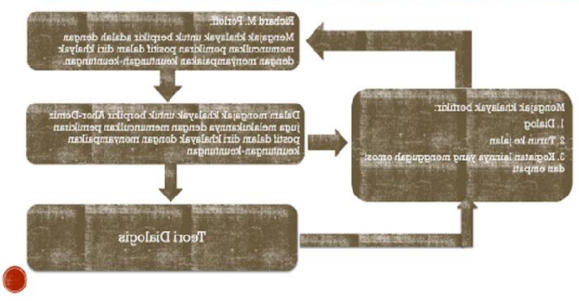

Jawa Barat meskipun popularitas dan elektabilitas di beberapa lembaga survei tidak unggul tapi pasangan ini bisa memenangkan Pilgub Jawa Barat tahun 2013 karena penguatan strategi, dampak

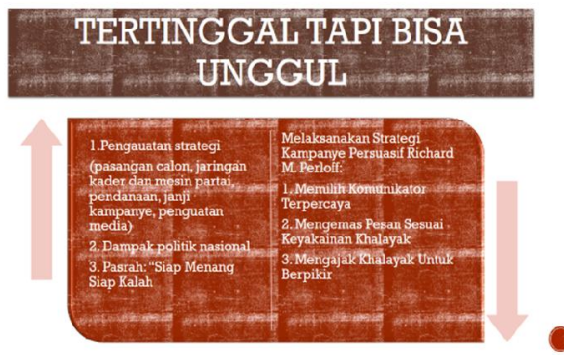

politik nasional, dan menerima dengan pasarah keputusan apapun, siap menang siap kalah. Serta melaksanakan strategi yang dilakukan Richard M. Perloff, khsusunya dalam memilih komunikator terpercaya, mengemas pesan yang sesuai dengan keyakinan khalayak, dan strategi mengajak khalayak berfikir ke arah yang postif.

Gambar 4. Faktor Kemangaan Ahmad Heryawan-Deddy Mizwar

Penetapan strategi merupakan langkah krusial yang memerlukan penanganan secara hati-hati dalam kampanye sebab jika penetapan strategi salah atau keliru, hasil yang diperoleh bisa fatal, terutama kerugian dari segi waktu, materi, dan tenaga. Oleh karena itu, strategi juga merupakan rahasia yang harus disembunyikan oleh para ahli perencana kampanye.

Kata strategi berasal dari Bahasa Yunani klasik, yaitu "stratos" yang artinya tentara dan kata "agein" yang berarti memimpin. Dengan demikian strategi dimaksudkan adalah memimpin tentara. Lalu muncul nama strategos yang artinya pemimpin tentara pada tingkat atas. Jadi, strategi adalah konsep militer yang bisa diartikan sebagai seni perang para jendral (the art of gendral) atau suatu rancangan yang terbaik untuk memanangkan peperangan. MarthinAnderson (1968) merumusakan "Strategi adalah seni yang melibatkan kemampuan intelegensi/pikiran untuk membawa semua sumber daya yang tersedia untuk mencapai tujuan dengan memperoleh keuntungan yang maksimal dan efisien. (Cangara, 2009:284)

Strategi politik identik dengan strategi kampanye. Masih Gungun Heryanto, strategi kampanye ini lebih merupakan prinsip pemikiran yang dikembangkan untuk mencapai tujuantujuan kampanye yang biasa terjabar dalam berbagai langkah taktis berdasarkan situasi dan kondisi lapangan. Kenyataan empiris menunjukan partai politik atau kandidat politik (melalui tim sukses masingmasing) memiliki strategi kampanye yang berbeda-beda dalam upaya meraih dukungan sebanyak-banyaknya. Ada beberapa prinsip pokok yang selayaknya memperoleh perhataian serius dalam mengembangan strategi kampanye, yakni positioning, branding, segmenting, strategi media, dan strategi non-media (forum-forum kampanye).

Setelah prinsip-prinsip pokok ini maka strategi kampanye dapat dikembangkan dengan memilih 
beberapa kemungkinan termasuk periklanan, sales promotion, pemasaran langsung, online marketing, dan hubungan masyarakat. Penting untuk dikemukakan bahwa baik penyusunan perencanaan maupun strategi kampanye mutlak membutuhkan pemahaman memadai mengenai situasi dan perilaku khalayak pemilih.

Sementara itu, tujuan dari sebuah kampaye adalah:

1. Kegiatan kampanye biasanya diarahkan untuk menciptakan perubahan pada tataran pengetahuan kognitif. Pada tahap ini, pengaruh yang diharapkan munculnya kesadaran, berubahnya keyakinan atau meningkatnya pengetahuan khalayak terhadap isu tertentu.

2. Pada tahap berikutnya, diarahkan pada perubahan sikap. Sasarannya adalah untuk memunculkan simpati, rasa suka, kepedulian atau keberpihakan khalayak pada isuisu yang menjadi tema kampanye.

3. Pada tahap akhir, kegiatan kampanye ditujukan untuk mengubah prilaku khlayak secara konkret dan terukur. Tahap ini, menghendaki adanya tindakan tertentu yang dilakukan oleh sasaran kampanye.

Untuk mewujudkan kampanye yang dapat memberikan pembelajaran kepada masyarakat dan dilaksanakan secara bertanggungjawab disamping menjadi ketertiban dan keamanan dalam berkampanye dibuat aturan main yang jelas. Untuk kasus di Indonesia, misalnya UU No. 10 tahun 2008 yang menetapkan beberapa larangan dalam berkampanye yaitu sebagai berikut:

1. Mempersoalkan dasar Negara Pancasila dan Pembukaan UUD Negara Republik Indonesia.
2. Melakukan kegiatan yang membahayakan keutuhan NKRI

3. Menghina seseorang, agama, suku, rasa, golongan, calon, dan atau peserta pemilu lain.

4. Menghasut dan mengadu domba antar perseorangan ataupun antar kelompok masyarakat

5. Mengganggu ketertiban umum; dalam hal ini adalah suatu keadaaan yang memungkinkan penyelenggaraan pemerintahan, pelayanan umum, dan kegiatan masyarakat tidak dapat berlangsung sebagaimana biasa.

6. Mengancam untuk melakukan kekerasan dan menganjurkan penggunaan kekerasan kepada seseorang, sekelompok anggota masyarakat dan atau peserta pemilu yang lain.

7. Merusak dan atau menghilangkan alat peraga kampanye peserta kampanye yang lain.

8. Menggunakan fasilitas pemerintah, tempat ibadah, dan tempat pendidikan (untuk tempat pendidikan dikecualikan atas prakarsa/izin dari pimpinan lembaga pendidikan dengan memberikan kesempatan yang sama kepada semua peserta pemilu, serta tidak menggangu proses belajar mengajar).

9. Membawa atau menggunakan tanda gambar dan atau atribut lain, selain tanda gambar dan atau atribut peserta pemilu yang bersangkutan.

10. Menjanjikan atau memberikan uang atau materi lainnya kepada peserta kampanye.

Dalam proses kampanye modern dewasa ini, tentu sudah tidak lagi berhenti pada pola kampanye lama, seperti manuver politik untuk menarik sebanyak mungkin pemilih dalam ajang 
pemilu demi meraih kesuksesan, sebab kampanye model lama ini hanya efektif dalam jangka pendek dan bisa menjadi bumerang bila setiap janji yang diungkapkan saat pemilu gagal direalisasikan. Kampanye lama yang dimaksudkan adalah kampanye politik yang dilakukan dalam periode tertentu sesuai toleransi waktu yang diberikan panitia pemilu dengan bertujuan memengaruhi khalayak atau masyarakat untuk memberikan hak suaranya dalam pencoblosan pemilu (Heryanto, 2013:23)

\section{Simpulan dan Saran}

Berdasarkan hasil temuan penelitian dan analisis hasil penelitian, maka dapat ditarik simpulan, sebagai berikut:

1. Strategi kampanye ditentukan oleh tim kampanye bersama pasangan calon. Ada lima strategi yang disusun untuk memenangkan pasangan Ahmad Heryawan-Deddy Mizwar dalam Pilgub Jawa Barat tahun 2015. Yakni penentuan pasangan calon yang layak jual, menguatkan mesin partai dan kader, pendanaan, janji kampanye, dan peranan media.

2. Strategi memilih komunikator yang terpercaya yang dilakukan pasangan Ahmad HeryawanDeddy Mizwar adalah melalui pasangan calon, juru kampanye, dan kader partai. Mereka yang terpilih adalah yang dapat dipercaya dengan memiliki kredibilitas. Sekalipun komunikator itu kader partai, tapi mereka dibekali tools pesan yang sudah rapi sesuai dengan janji kampanye. Apa yang dilakukan oleh pasangan Ahmad Heryawan-Deddy Mizwar ini sesuai dengan yang dikemukakan dalam konsep kampanye persuasif Richard M. Perloff, yakni pilihlan komunikator yang terpercaya.

3. Strategi memilih pesan yang seusai dengan keyakinan khalayak yang dilakukan pasangan Ahmad HeryawanDeddy Mizwar adalah dilakukan dalam bentuk langsung (melalui kampanye, silaturahmi, dll), maupun tidak langsung (melalui media), Materi pesannya berisi tentang keberhasilan Ahmad Heryawan, janji kampanye, dan program kerja. Pesan yang disampaikan tidak bohong dan tidak manipulasi, benar adanya. Sementara isi pesannya umum (disampaikan saat kampanye) dan khusus (disampaikan pada komunitas tertentu). Pesan yang disampaikan harus menjadi kepercayaan dari khalayak. Apa yang dilakukan oleh pasangan Ahmad Heryawan-Deddy Mizwar ini sesuai dengan apa yang dikemukakan dalam konsep kampanye persuasif Richard M. Perloff, yakni kemaslah pesan sesuai dengan keyakinan khalayak.

4. Strategi mengajak khalayak berpikir saat kampanye pada pasangan Ahmad HeryawanDeddy Mizwar pada Pilgub Jawa Barat dilakukan dengan dialog, turun ke jalan, dan melakukan kegiatan yang bersentuhan dengan emosi dan budaya, dll. Apa yang dilakukan oleh pasangan Ahmad Heryawan-Deddy Mizwar ini sesuai dengan apa yang dikemukakan dalam konsep kampanye persuasif Richard M. Perloff, yakni ajaklah khalayak untuk berfikir.

5. Faktor kemenangan Ahamd Heryawan-Deddy Mizwar dalam 
Pilgub Jawa Barat meskipun popularitas dan elektabilitas di beberapa lembaga survei tidak unggul tapi pasangan ini bisa memenangkan Pilgub Jawa Barat tahun 2013 karena penguatan strategi, dampak politik nasional, dan menerima dengan pasarah keputusan apapun, siap menang siap kalah. Serta melaksanakan strategi yang dilakukan Richard $\mathrm{M}$. Perloff, khsusunya dalam memilih komunikator terpercaya, mengemas pesan yang sesuai dengan keyakinan khalayak, dan strategi mengajak khalayak berfikir ke arah yang postif.

Berdasarkan penelitian yang dilakukan, peneliti mengajukan saransaran, baik rekomendasi secara teoritis mapun praktis yang keseluruhnya mengacu pada kegunaan penelitian. Adapun saran-saran tersebut, sebagai berikut:

1. Peneliti akui masih banyak kekurangan dan jauh dari sempurna dalam melakukan penelitiaan ini. Oleh sebab itu, peneliti mengharapkan jika ada penelitian serupa dapat meneliti lebih detail lagi. Sehingga mencapai mutu politik yang sangat diharapkan oleh masyarakat.

2. Strategi kampanye merupakan hal yang harus dilakukan karena memiliki tujuan agar pemilih bisa menentukan pilihannya kepada salah seorang kandidiat dalam sebuah pertarungan politik seperti dalam pemilihan umum. Strategi memilih komunikator untuk sebuah kampanye pemilu tidak gampang, butuh orang yang kredibel sehingga bisa dipercaya masyarakat yang pada akhirnya bisa memilih calon yang tim atau juru kampanye sosialisasikan.

3. Strategi menyusun pesan pun perlu dilakukan dengan cermat. Penyampaian pesan harus dilakukan dengan berbagai cara baik langsung maupun tidak langsung. Saluran, isu, dan temanya pun harus benar-benar tepat agar, khalayak percaya terhadap pesan yang disampaikan dan bisa memilih kandidat yang "dipasarkannya".

4. Strategi pelibatan khalayak dalam kampanye sangat dibutuhkan. Terlebih saat ini masyarakat membutuhkan sosok pemimpin yang dekat dengan masyarakat. Ajak mereka untuk dialog, melakukan kegiatan, bekerja bersama membantu masyarakat. Tunjukan bahwa kandidat memang orang yang berkualitas, siap bekerja, dan dekat dengan masyarakat. Kekuatan jaringan merupakan hal terpenting dalam pemenangan pemilu. Pelibatan kader dan mesin partai adalah salah satu untuk memperkuat jaringan.

\section{Daftar Pustaka}

Cangara, Hafied. 2009. Komunikasi Politik Konsep, Teori, dan Strategi. Bandung: Rajawali Press.

Ardianto, Elvinaro, Bambang Q-Anees. 2014. Filsafat Ilmu Komunikasi. Bandung: Simbiosa Rekatama Media.

Heryanto, Gungun dan Sulhan Rumaru. 2013. Komunikasi Politik, Sebuah Pengantar. Jakarta: Ghalia Indonesia. 